\title{
BLOOD HEMATOLOGICAL VALUES OF BOSNIAN MOUNTAIN HORSES
}

\author{
Dunja Rukavina ${ }^{1}$, Mirela Mačkić-Đurovićc ${ }^{2}$, Agnesa Ćoralić3, Denis Čamo ${ }^{3}$, Amir Zahirović \\ ${ }^{1}$ Department of Biology, Veterinary Faculty, University of Sarajevo, \\ Zmaja od Bosne 90, 71000 Sarajevo, Bosnia and Herzegovina \\ ${ }^{2}$ Center for Genetic, Faculty of Medicine, University of Sarajevo, \\ Čekaluša 90, 71000 Sarajevo, Bosnia and Herzegovina \\ ${ }^{3}$ Department of Internal Diseases, Veterinary Faculty, University of Sarajevo, \\ Zmaja od Bosne 90, 71000 Sarajevo, Bosnia and Herzegovina \\ dunja.rukavina@vfs.unsa.ba
}

\begin{abstract}
The objective of the present study was to investigate values of hematological parameters in Bosnian mountain horses. Eleven hematological measurements were performed on 30 clinically healthy adult horses of mixed age and both genders. Blood samples were obtained by jugular vein puncture (vena jugularis externa) in vacuum tubes with EDTA and determined using an automated analyzer IDEXX QBC VET AutoRead. Mean value of HB was higher than recommended reference intervals for adult horses in general while mean values of MONO and EOS counts were slightly above reference intervals for adult ,warm-blooded“ horses. The specific hematological values determined in Bosnian mountain horses may be related to the immune condition of investigated breed that is well adapted to environmental and climatic conditions and should be taken into consideration when dealing with this horse breed.
\end{abstract}

Key words: Bosnian mountain horse; hematological parameters; values

\section{ХЕМАТОЛОШКИ ВРЕДНОСТИ НА КРВТА НА БОСАНСКИТЕ ПЛАНИНСКИ КОЮИ}

\begin{abstract}
Целта на оваа студија беше да се испитаат вредностите на хематолошките параметри кај босанските планински коњи. Беа извршени единаесет хематолошки мерења на 30 клинички здрави возрасни коњи од различна возраст и од двата пола. Примероците од крвта се добиени со јунуларна венска пункција (vena jugularis externa) во вакуумски епрувети со EDTA и детерминирани се со користење на автоматски анализатор IDEXX QBC VET AutoRead. Средната вредност на HB беше повисока од препорачаните референтни интервали за возрасни коњи во целина, додека средните вредности на MONO и EOS беа нешто над референтните интервали за возрасни "топлокрвни" коњи. Вредностите на RBC, HCT и HB беа на горната граница или повисоки од вредностите објавени во претходните испитувања. Специфичните хематолошки вредности утврдени кај босанските планински коњи можат да бидат поврзани со имунолошката состојба на испитуваната раса која е добро приспособена на еколошките и климатските услови, што треба да се земе предвид кога се работи за оваа раса на коњот.
\end{abstract}

Клучни зборови: босански планински коњ; хематологија; параметри

\section{INTRODUCTION}

Hematological parameters in horses are frequently used as an aid for clinical diagnosis of organic, infectious and some parasitic diseases. They are also used to provide information about metabolic state of an animal, the recovery monitoring, treating the diseases and in postoperative patients (Satue et al., 2009; Mikniene et al., 2014). It is used in sport horses to plan specific physical exercise (Altinsaat, 2008). Interpretation of hematological parameters is challenging because many exogenous and endogenous factors modify blood parameters (Satue et al., 2009). In interpreting laboratory test 
results of an individual, the clinician usually compares the observed values with reference values. The hematological values obtained abroad may not be fully applicable under local conditions because these are influenced by multiple factors including breed, environmental and management differences.

Some variations also exist in results between laboratories using different reagents, methods and instruments (Gul et al., 2007). The blood profile of horses can be influenced by their temperament; which classifies horses as Hotbloods (HB), Warmbloods (WB) and Coldbloods (CB) (Lacerda et al., 2006). Bosnian mountain horse (Bosnian and Herzegovinian mountain horse, Bosnian pony) is classified as WB horse. Due to their size and type it belongs to the largest group of ponies. This breed is the only autochthonous horse breed in Bosnia and Herzegovina (B\&H), well adapted to ecological and geographical conditions of the region and have characteristics that might be reflected in their hematological parameters (Žiga and Telalbašić, 2009; Dekić et al., 2014).

Hematological parameters of horses have been investigated, including Lipizzan (Čebulj-Kadunc et al., 2002), Kathiawari (Gupta et al., 2002), Criollo and Brasileiro de Hipismo (Lacerda et al., 2006), apparently healthy horses from Faisalabad city - Pakistan (Gul et al., 2007), Arabian horses (Altinsaat, 2008), Pakistan horses (Pritchard et al., 2009), Etiopian (Simenev et al., 2011), horses from Nigeria (Ebge-Nwiyi et al., 2012), Standardbred (Jagrič et al., 2012), Kiso horses (Takasu et al., 2013), Žemaitukai (Mikniene et al., 2014), Posavina and Croatian Coldblood (Pađen et al., 2014) and Hucul horses (Cywinska et al., 2015).

The information about the ancient Bosnian mountain horse breed is limited in the literature for the moment. Thus, the aim of this study was to investigate mean values of hematological parameters in clinically healthy adult Bosnian mountain horses and to compare obtained results with results previously reported for other breeds of horses, reference intervals for adult horses in general and adult WB horses.

\section{MATERIALS AND METHODS}

Blood samples were collected in May 2014, on stud farm Borike (altitude of $950 \mathrm{~m}$ ). The study was carried out on 30 clinically healthy adult horses of both gender (16 females and 14 males) with ages between two and twenty-three years. Means $\pm \mathrm{SD}$ of age were $9.9 \pm 6.0$ and $7.9 \pm 2.3$ years for females and males, respectively.

Applying molecular markers were found that horses are constituted of indigenous Bosnian mountain horses and no genetic differentiation between them was observed (Rukavina et al., 2015). Blood samples were collected in the morning before feeding and watering. All the individuals, except stallions, were kept in outdoor conditions, on pastures of a mountainous plateau. During the winter period they are also mostly outdoors, fed with hay.

Blood samples were obtained by jugular vein puncture (vena jugularis externa) in vacuum tubes with anticoagulant (EDTA). The number of red blood cells $(\mathrm{RBC})\left(\times 10^{12} / \mathrm{l}\right)$, hematocrit $(\mathrm{HCT})(\%)$, hemoglobin concentration $(\mathrm{HB})(\mathrm{g} / \mathrm{dl})$, mean corpuscular hemoglobin concentration (MCHC) (g/dl), platelet cells (PLT) $\left(\times 10^{9} / 1\right)$, total number of leukocytes/white blood cells (WBC) $\left(\times 10^{9} / 1\right)$, neutrophils (NEU) $\left(\times 10^{9} / 1\right)$ lymphocytes (LYM) $\left(\times 10^{9} / 1\right)$, monocytes (MONO) $\left(\times 10^{9} / 1\right)$, eosinophils (EOS) $\left(\times 10^{9} / 1\right)$ and basophils (BASO) $\left(\times 10^{9} / 1\right)$ were determined using an automated cell counter IDEXX QBC VET AutoRead (IDEXX, Netherland).

Data were analyzed with descriptive statistics in SPSS 17.0 (SPSS Inc., Chicago, IL, USA) and Microsoft excel 2010. All animals were treated in accordance to Internal Ethical Committee by respecting animal welfare and well-being.

\section{RESULTS AND DISCUSSION}

Data regarding hematological values in Bosnian mountain horse breed are limited in the literature for the moment. For that reason, the need for a reference range of values for hematological parameters in Bosnian mountain horse breed becomes evident. In the present study, results of basic hematological parameters were provided. Results of mean values with standard deviation $( \pm \mathrm{SD})$ and range of hematological parameters in clinically healthy adult Bosnian mountain horses, reference intervals for adult horses in general (Freeman and Klenner, 2015) and adult WB horses (Freeman and Klenner, 2015; Čebulj-Kadunc et al., 2002) are shown in Table 1. A total of eleven hematological parameters were determined. Mean value of HB was higher than recommended reference intervals for adult horses in general while mean values of MONO and EOS were slightly above reference intervals for adult WB horses. 
Table 1

Reference intervals for adult horses in general and WB horses, mean, standard deviation ( $\pm S D)$ and ranges of hematological parameters in Bosnian mountain horses

\begin{tabular}{lcccccc}
\hline \hline Parameter & $\begin{array}{c}\text { Reference intervals } \\
\text { for adult horse }\end{array}$ & $\begin{array}{c}\text { Reference intervals } \\
\text { for adult WB horse }\end{array}$ & Mean & SD & Min & Max \\
\hline RBC $\left(\times 10^{12} / 1\right)$ & $5.5-9.5$ & $6.5-11$ & 8.62 & 1.45 & 6.71 & 11.93 \\
HCT $(\%)$ & $24-45$ & $32-53$ & 42.47 & 8.41 & 31.30 & 62.80 \\
HB $(\mathrm{g} / \mathrm{dl})$ & $8-14$ & $10-18$ & 15.15 & 2.55 & 11.50 & 22.80 \\
MCHC $(\mathrm{g} / \mathrm{dl})$ & $34-38$ & $34-38$ & 35.14 & 2.29 & 27.70 & 39.40 \\
WBC $\left(\times 10^{9} / 1\right)$ & $6-12$ & $5-10$ & 9.33 & 3.59 & 4.76 & 21.50 \\
PLT $\left(\times 10^{9} / 1\right)$ & $100-360$ & $103-244$ & 212.10 & 78.00 & 95.00 & 383.00 \\
NEU $\left(\times 10^{9} / 1\right)$ & $3.0-6.3$ & $3-7$ & 5.56 & 2.31 & 2.85 & 12.00 \\
LYM $\left(\times 10^{9} / 1\right)$ & $1.3-4.3$ & $1.5-4.0$ & 2.42 & 1.24 & 0.67 & 6.80 \\
MONO $\left(\times 10^{9} / 1\right)$ & $0.0-1.0$ & $0.0-0.5$ & 0.63 & 0.27 & 0.32 & 1.20 \\
EOS $\left(\times 10^{9} / 1\right)$ & $0.0-1.0$ & $0.0-0.4$ & 0.70 & 0.41 & 0.11 & 1.45 \\
BASO $\left(\times 10^{9} / 1\right)$ & $0.0-0.3$ & - & 0.08 & 0.02 & 0.01 & 0.08 \\
\hline \hline
\end{tabular}

The values of basic hematological parameters (WBC, RBC, HCT, HB, MCV, MCH, MCHC) of Bosnian pony from the Borike Stud are available in literature (Dekić et al., 2014). The mean values of HCT and HB detected in our study were similar with results referred by Dekić et al. (2014). However, mean values of $\mathrm{RBC}$ and $\mathrm{MCHC}$ were lower, while mean value of $\mathrm{WBC}$ was higher than values given by Dekić et al. (2014). Obtained differences could be due to sample size, different used methods, reagents and instruments. Mean RBC value in Bosnian mountain horses was similar or in upper limit to $\mathrm{RBC}$ values in Criollo $\left(8.59 \times 10^{12} / 1\right)$ (Lacerda et al., 2006), Arabian $\left(8.89 \times 10^{12} / 1\right)$ (Altinsaat, 2008), Standardbred $\left(8.89 \times 10^{12} / 1\right)$ (Jagrič et al., 2012), Žemaitukai $\left(7.74-8.36 \times 10^{12} / 1\right)$ (Mikniene et al., 2014) and Thoroughbreed horses $\left(9.0 \times 10^{12} / 1\right)$ (Pađen et al., 2014). Higher mean RBC value was reported by Cywinska et al. (2015) for Hucul horses $\left(10.1 \times 10^{12} / 1\right)$. The $\mathrm{RBC}$ values detected in our study were higher than that reported for other horse breeds (4.97-8.18 $\left.\times 10^{12} / 1\right)$ (Čebulj-Kadunc et al., 2002; Gupta et al., 2002; Lacerda et al., 2006; Gul et al., 2007; Pritchard et al., 2009; Simenev et al., 2011; Ebge-Nwiyi et al., 2012; Takasu et al., 2013; Pađen et al., 2014).

Results for a mean value of HCT, obtained in our study, were similar to HCT values in Lipizzan (39-43\%) (Čebulj-Kadunc et al., 2002), Arabian (37.33-43.89\%) (Altinsaat, 2008) and Hucul horses
(43\%) (Cywinska et al., 2015). Mean values of HCT reported in the literature for other horse breeds mostly ranged from $30.84 \%$ to $39.5 \%$ (Gupta et al., 2002; Lacerda et al., 2006; Gul et al., 2007; Pritchard et al., 2009; Simenev et al., 2011; EbgeNwiyi et al., 2012; Jagrič et al., 2012; Takasu et al., 2013; Mikniene et al., 2014; Pađen et al., 2014) and were lower than the one we detected.

The mean HB value, obtained in our study, was higher than the recommended reference intervals for adult horses in general $(8-14 \mathrm{~g} / \mathrm{dl})$ and was in the upper limit to the recommended reference ranges for adult WB horses (10-18 g/dl) (Freeman and Klenner, 2015). The values of HB found in this study were higher than values reported in previous studies on different horse breeds (8.9-14.1 g/dl) (Čebulj-Kadunc et al., 2002; Gupta et al., 2002; Lacerda et al., 2006; Gul et al., 2007; Altinsaat, 2008; Pritchard et al., 2009; Simenev et al., 2011; Ebge-Nwiyi et al., 2012; Jagrič et al., 2012; Takasu et al., 2013; Mikniene et al., 2014; Pađen et al., 2014; Cywinska et al., 2015). According to Satue et al. (2009) values of HB are higher in the spring. Blood samples used in this work were collected in May and obtained results of HB values supports the hypothesis of Satue et al. (2009). Also, higher values of HB, as well as RBC and HCT values, detected in the present study, may be explained with adaptation of Bosnian mountain horses to the environmental and climatic conditions. According to 
Satue et al. (2009) horses subjected to high altitude have higher RBC, HB and HCT values, compared to animals that live at less altitude. It is considered a compensatory mechanism for the lower content of oxygen in the atmospheric air, which is proportionally reduced to the altitude (Wickler and Anderson, 2000).

The mean MCHC value in Bosnian mountain horses was similar to the previously cited values for horses from Etiopia $(37.02 \mathrm{~g} / \mathrm{dl}$ ) (Simenev et al., 2011) and Nigeria (38.26 g/dl) (Ebge-Nwiyi et al., 2012). In Mikniene et al. (2014) research on Žemaitukai horses, a mean values of MCHC were higher (42.41-44 g/dl), while in Lipizzan (31.4-32 g/dl) (Čebulj-Kadunac et al., 2002), Kathiawari (28.02-29.08 g/dl) (Gupta et al., 2002), Arabian (30.38 - $31.13 \mathrm{~g} / \mathrm{dl})$ (Altinsaat, 2008) and Hucul horses (20.9 g/dl) (Cywinska et al., 2015) mean values of MCHC were lower than the one we detected. This result could be explained by higher RBC and HB concentrations obtained in the present study.

The mean value of $\mathrm{WBC}$, obtained in our study, was similar to WBC values in Arabian (7.73$9.16 \times 10^{9} / 3$ ) (Altinsaat, 2008), Nigerian horses $\left(9.38 \times 10^{9} / 1\right) \quad$ (Ebge-Nwiyi et al., 2012) and Žemaitukai horses $\left(9.29-9.48 \times 10^{9} / 1\right)$ (Mikniene et al., 2014). Lower values were detected in Lipizzan (7.48-7.56×10 $/ 1)$ (Čebulj-Kadunac et al., 2002), Brasileiro de Hipismo $\left(7.61 \times 10^{9} / 1\right)$ (Lacerda et al., 2006), apparently healthy horses from Faisalabad city $\left(7.18 \times 10^{9} / 1\right)$ (Gul et al., 2007), Standardbred $\left(6.21 \times 10^{9} / 1\right)($ Jagrič et al., 2012) and Kiso horses $\left(8.27 \times 10^{9} / 1\right)$ (Takasu et al., 2013) while in Kathiawari $\left(11.22-12.72 \times 10^{9} / 1\right)$ (Gupta et al., 2002), Criollo $\left(11.13 \times 10^{9} / 1\right)($ Lacerda et al., 2006), Etiopian $\left(11.19 \times 10^{9} / 1\right)$ (Simenev et al., 2011) and Hucul horses $\left(12.4 \times 10^{9} / 1\right)($ Cywinska et al., 2015) were detected higher mean values of WBC. Differences in leucocyte counts may be altered by factors such as age, nutritional status, pregnancy and lactation (Reece, 1997).

Equine platelet concentrations are some of the lowest reported for mammals (Satue et al., 2009). The values of PLT, found in this study, were higher than values reported for Žemaitukai horses (144.55$\left.150.54 \times 10^{9} / 1\right)$ (Mikniene et al., 2014) and were similar to values reported for Etiopian $\left(207.65 \times 10^{9} / 1\right)$ (Simenev et al., 2011) and Hucul horses (231.7 $\left.\times 10^{9} / 1\right)($ Cywinska et al., 2015).

The mean value of NEU count detected in our study was similar to Lacerda et al. (2006) research on Criollo horses $\left(4.9 \times 10^{9} / 1\right)$ and Altinsaat $(2008)$ research on Arabian horses $\left(3.78-6.26 \times 10^{9} / 1\right)$, but lower than a mean values reported for Posavina and Croatian Coldblood horses $\left(6.46 \times 10^{9} / 1\right)$ (Pađen et al., 2014) and Hucul horses $\left(6.8 \times 10^{9} / 1\right)$ (Cywinska et al., 2015). For Brasileiro de Hipismo horses was reported lower mean value of NEU count (4.14 $\left.\times 10^{9} / 1\right)$ (Lacerda et al., 2006).

Results for a mean value of LYM count detected in our study, was similar to values reported for Arabian (2.32-5.9×10 $/ 1)$ (Altinsaat, 2008), Standardbred $\left(2.57 \times 10^{9} / 1\right)$ (Jagrič et al., 2012) and Žemaitukai horses $\left(2.38-2.72 \times 10^{9} / 1\right)$ (Mikniene et al., 2014) but lower than that found for other investigated horse breeds $\left(3.62-6.1 \times 10^{9} / 1\right)$ (Lacerda et al., 2006; Ebge-Nwiyi et al., 2012; Pađen et al., 2014). According to Satue et al. (2009) LYM count is higher in the evening and lower in the morning. Samples used in this work were collected in the morning and obtained results support the hypothesis.

In this study, a mean value of MONO count was higher than recommended reference intervals for adult WB horses $\left(0.0-0.5 \times 10^{9} / 1\right)$ (Freeman and Klenner, 2015) and than values previously reported for other horse breeds $\left(0.02-0.40 \times 10^{9} / 1\right)$ (Lacerda et al., 2006, Ebge-Nwiyi et al., 2012; Jagrič et al., 2012; Pađen et al., 2014; Cywinska et al., 2015).

Mean value of EOS count was higher than recommended reference intervals for adult WB horses $\left(0.0-0.4 \times 10^{9} / 1\right)$ (Freeman and Klenner, 2015). Higher values of EOS counts were obtained in Arabian horses $\left(1.7-2.7 \times 10^{9} / 1\right)$ (Altinsaat, 2008) and Posavina and Croatian Coldblood horses (0.85 $\left.\times 10^{9} / 1\right)$ (Pađen et al., 2014). Lower values of EOS count were published for other horse breeds $(0.16$ $0.31 \times 10^{9} / 1$ ) (Lacerda et al., 2006; Ebge-Nwiyi et al., 2012; Jagrič et al., 2012; Cywinska et al., 2015). Increased EOS count, found in this study, may be associated with parasitic damage of epithelial cells because mares were kept in an open area, exposed to various parasite infestations.

Results for a mean value of BASO count, obtained in this study were similar to values reported for Posavina and Croatian Coldblood horses $(0.08$ $\left.\times 10^{9} / 1\right)($ Pađen et al., 2014) and Hucul horses $(0.07$ $\left.\times 10^{9} / 1\right)($ Cywinska et al., 2015). Jagrič et al. (2012) reported higher value for BASO count in Standardbred horses $\left(0.35 \times 10^{9} / 1\right)$ while Lacerda et al. (2006) found lower values in Brasileiro de Hipismo and Criollo horses $\left(0-0.017 \times 10^{9} / 1\right)$.

Generally, differences detected in values of observed hematological parameters could be due to breed, differences in geographical, physiological, season and climate conditions of sampled horses as 
well as nutritional factors, management and sample size. Also, differences in hematological parameters could be attributed to different reagents, methods and applied instruments.

With slight differences, results of hematology parameters, detected in our study, confirmed that Bosnian mountain horse belong to WB horses. Obtained hematological values of Bosnian mountain horse breed were intermediate between the two other hot-blooded and cold-blooded horse breeds. More similarity was observed with hot-blooded Arabian horse breed. This result was not unexpected and could be explained by fact that Bosnian mountain horse breed is Arabian ancestral origin.

In conclusion, higher values of RBC, HCT and $\mathrm{HB}$ in Bosnian mountain horses may be related to the immune condition of investigated breed that is well adapted to environmental and climatic conditions suggesting that the adaptation process generated physiological changes. The specific hematological values determined in Bosnian mountain horses should be taken into consideration when dealing with this breed of horses.

Conflict of interest: There is no conflict of interest.

Acknowledgment. The study was supported by Federal Ministry of Education and Science of the Federation of Bosnia and Herzegovina, Bosnia and Herzegovina. Project No 1000039, 2013.

\section{REFERENCES}

[1] Altinsaat, C.: The effects of age and gender on blood parameters in Arabian horses. Kafkas Univ Vet Fak Derg., 14 (2), 173-178 (2008).

[2] Cywinska, A., Czopowicz, M., Witkowski, L., Gorecka, R., Degorski, A., Guzera, M., Szczubelek, P., Turlo, A., Schollenberger, A., Winnicka, A.: Reference intervals for selected hematological and biochemical variables in Hucul horses. Polish J. Vet. Sci., 18 (2), 439-445 (2015).

[3] Čebulj-Kadunc, N., Božić, M., Kosec, M., Cestnik, V.: The influence of age and gender on haematological parameters in Lipizzan horses. J. Vet. Med. A., 49, 217-221 (2002).

[4] Dekić, R., Ivanc, A., Cetković, D., Doličanin, Z., Obradović S.: Hematology of Bosnian pony. Bulgarian J. Agricult. Sci., 20 (5), 1237-1244 (2014).

[5] Ebge-Nwiyi, T. N., Kalu, N. A., Naphtali, C.: Preliminary studies on some haematological and serum biochemical parameters of apparently healthy adult horses in Maiduguri, Nigeria. Afr. J. Biomed. Res.,15, 49-53 (2012).
[6] Freeman, P. K., Klenner, S.: Veterinary Clinical Pathology. A case-based approach. CRS Press, Taylor \& Franas Group, Boca Raton, London, New York, 2015.

[7] Gul, S. T., Ahmad, M., Khan, A., Hussain, I.: Haematobiochemical observations in apparently healthy equine species. Pakistan Vet. J., 27 (4), 155-158 (2007).

[8] Gupta, A. K., Kumar, S., Pal, Y.: Biochemical, haematological and thyroid hormone profile in healthy Indian Kathiawari horses. Asian-Aust J. Anim. Sci., 15 (8), 12151221 (2002).

[9] Jagrič, M. S., Nemec, S. A., Zrimšek, P., Kramarič, P., Kos Kadunc, V., Vovk, T., Kobal, S.: Plasma malondialdehyde, biochemical and haematological parameters in standardbred horses during a selected field exercise test. Acta Vet.Beograd, 62, 53-65 (2012).

[10] Lacerda, L., Campos, R., Sperb, M., Soares, E., Barbosa, P., Godinho, E., Ferreira, R., Santos, V., Gonzalez, F. D.: Hematologic and biochemical parameters in three high performance horse breeds from Southern Brazil. Arch. Vet. Sci., 11 (2), 40-44 (2006).

[11] Mikniene, Z., Maslauskas, K., Kerziene, S., Kučinskiene, J., Kučinskas, A.: The effect of age and gender on blood haematological and serum biochemical parameters in Žemaitukai horses. Vet. Med. Zoot., 65 (87), 37-43 (2014).

[12] Pađen, L., Gomerčić, T., Đuras, M., Arbanasić, H., Galov, A.: Hematological and serum biochemical reference values for the Posavina and Croatian coldblooded horse breeds. Acta Vet. Beograd, 64 (2), 200-212 (2014).

[13] Pritchard, J. C., Burn, C. C., Barr, A. R. S., Whay, H. R.: Haematological and serum biochemical reference values for apparently healthy working horses in Pakistan. Res. Vet. Sci., 87, 389-395 (2009).

[14] Reece, W. O.: Physiology of Domestic Animals, ed. William Reece. Williams \& Wilkins, New York, 1997.

[15] Rukavina, D., Hasanbašić, D., Pojskić, N., Ramić, J., Zahirović, A., Ajanović, A., Beganović, K., Durmić-Pašić, A.: Analysis of genetic diversity among certain horse breeds from Bosnia and Herzegovina. Veterinaria, 64 (1), 25-29 (2015).

[16] Satue, K., Blanco, O., Munoz, A.: Age-related differences in the hematological profile of Andalusian broodmares of Carthusian strain. Veterinary Medicine, 54, 175-182 (2009).

[17] Simenew, K., Gezahegne, M., Getachew, M., Wondyefraw, M., Alemayehu, L., Eyob, I.: Reference values of clinically important physiological, hematological and serum biochemical parameters of apperantly helthy working Equids of Ethiopia. Global Veterinaria, 7, 1-6 (2011).

[18] Takasu, M., Nana Nagatani, N., Tozaki, T., Kakoi, H., Maeda, M., Murase, T., Mukoyama, H.: Hematological and Biochemical Reference Values for the Endangered Kiso Horse. J. Equine Sci., 24 (4), 75-78 (2013).

[19] Wickler, S. J., Anderson, T. P.: Hematological changes and athletic performance in horses in responsse to high altitude $(3.800 \mathrm{~m})$. Am. J. Physiol. Regul. Integr. Comp. Physiol., 279 (4), 1176-1181 (2000).

[20] Žiga, E., Telalbašić, R.: The Bosnian Mountain Horse - A monograph. IP Šahimpašić, Sarajevo, 2009. 
